\author{
Ramin Asadi ${ }^{1}$; James Olabode Bamidele Rotimi ${ }^{2}$; and Suzanne Wilkinson ${ }^{3}$
}

${ }^{1} \mathrm{Ph} . \mathrm{D}$. Student, School of Built Environment, Massey Univ., Auckland 0632, New Zealand (corresponding author). ORCID: https://orcid.org/0000 -0002-2073-3557. Email: R.asadi@massey.ac.nz

${ }^{2}$ Associate Professor, School of Built Environment, Massey Univ., Auckland 0632, New Zealand.

${ }^{3}$ Professor, School of Built Environment, Massey Univ., Auckland 0632, New Zealand.

Note. This manuscript was submitted on April 15, 2021; approved on September 30, 2021№ Epub Date. Discussion period open until 0, 0; separate discussions must be submitted for individual papers. This paper is part of the Journal of Legal Affairs and Dispute Resolution in Engineering and Construction, (C) ASCE, ISSN 1943-4162. documents is one of the sources of claims and conflicts. Because the adverse effects of a claim are predictable by the contractual parties, the occurrence of dispute cases is preventable. Thus, the method of dealing with the claim and reimbursing its impacts needs to be defined. If the contractual parties successfully reach an agreement, the claim would be managed; otherwise, it results in disputes. Overall, the claim progression procedure has been placed in the contract conditions to legitimize claim assessment and avoid the occurrence of disputes (Abdul-Malak et al. 2020). Furthermore, the mechanisms of claim assessments and their solutions are almost always addressed in the standard forms of contract conditions in the construction industry. However, understanding the contractual terms among these contracts is not easy for all construction practitioners because the conditions are articulated by legal entities (Raj et al. 2009).

A comprehensive review of the literature revealed insufficient research identifying the relationship of rework and claim. How contractual claims are affected and may result in dispute has not been studied yet under rework circumstances. Therefore, there is a need to investigate the causes of rework in association with contractual construction claims. Because contractual claims are referred to in the contract conditions (Jelodar et al. 2016), rework causes generating such claims can also be referenced to the same conditions. For example, a claim could cover the client's changes when appropriately incorporated into the contract's relevant clause. Concurrently, the imposed changes may result in rework occurrence. Due to the similarity of the causes between claim and rework in this example, the relevant contract conditions for addressing change can be utilized for addressing rework. This paper attempts to provide the basis for further research on contract conditions and their potential to address rework by identifying relationships between claims and rework causes. As a result, it is necessary to characterize this relationship first through examining their common root causes. The reported study in this paper uses a review approach to identify common causes of rework and then explores the relationship between rework and claims. The objectives of this study include the following: 
1. To identify rework causes that generate contractual claims and establish the relationship between rework and claim, and

2. To investigate if rework is addressed adequately in the general conditions of the contract in construction project.

The study examines the standard form of contract for building and civil engineering construction NZS 3910-2013 (Standard New Zealand 2013) as the most commonly used contract document in New Zealand construction projects for achieving Objective 2. NZS 3910 has been designed to be flexible for industry uses and includes the required provisions to cover a variety of engineering and building projects with different administration methods.

\section{Need to Explore Contract Conditions in Rework Circumstances}

To some extent, contract conditions have been shaped in a standard format in the construction projects of many countries. Based on the literature review, claims and associated disputes can be related to contract conditions, so their underlying causes, such as rework, can systematically be linked to the contract conditions. From the literature it can be implied that rework triggers a claim, and poor contract conditions make the scenario even more complicated (Besaiso et al. 2018). This paper intends to make contribution to rework by improving contract management on construction projects. Rework causes are very complex and interrelated. Many researchers have studied rework in the design and construction stages of projects but studying rework in the procurement stage is very limited. The contract document is the main output of the procurement stage of a project, and poor contract documentation has been identified as a major contributing factor to the occurrence of rework (Love et al. 2006; Mendis et al. 2013, 2015). In addition, contract provisions play a critical role in claim handling and can prevent disputes. Therefore, the focus of the research reported in this paper is to understand the relationship between rework and contractual claims and explore the adequacy of the conditions of the contract in addressing their common causes. Understanding this relationship is vital because it ultimately serves as a framework for improving the general conditions of the contract. Proposing further recommendations for revising the current format of contract conditions to address rework would result in better management of claims and disputes. It could enhance the contract provisions as part of the solution for claim handling that is incorporated into dispute prevention.

\section{Common Sources of Claim and Rework in Construction Projects}

There is an interdependent relationship between rework and contractual claims of construction projects (Palaneeswaran et al. 2014; Ajayi and Oyeyipo 2015). Correlation coefficient analysis through neural network modeling showed that contractual claims and rework were significantly related (Palaneeswaran et al. 2006). Therefore, rework consistently pushes contractors looking for claims to compensate for cost and delayed time, specifically when rework influences the budget and critical path of the project. Despite a strong correlation between rework and claims, the investigation of their relationship is limited in the literature; however, extensive research has been dedicated to each subject separately. Due to the scarcity of empirical research, this paper aims to examine claims under rework manifestations. Rework has been introduced as one of the causes of claims in various studies (Love and Curtin 2020; Eze and Idiake 2018; Wang et al. 2019; Banwo et al. 2015). Rework, and claims, cause overruns and delays that ultimately lead to poor project performance. The effects of rework on a construction project have been studied in Nigeria and the result showed that contractual claims are reduced when rework triggers are eliminated (Eze et al. 2018a). Causes of rework can be examined under various claim situations. Take an example of a material shortage in the market that generally ends with using alternative material, but the contractor needs to obtain the client's preapproval for the material replacement. In this way, contractors save their position to be eligible for a claim in the future, while using alternative material is one of the root causes of rework in many projects.

The sources of claim and rework are common in many circumstances. For example, when changes occur, they cannot be isolated due to the existing interrelated chain of cause and effect. If the contractors are not sure about compensation for rework costs, they are unlikely to perform requested changes with priority, and therefore claims appear. Jelodar et al. (2016) categorized causes of claims into three main groups: (1) project uncertainties, (2) contract and process, (3) people, and behavior. The causes of claims in United Arab Emirates (UAE) construction projects were investigated and the results identified seven types of claim to be contract ambiguity, delay, acceleration, changes, extra work, errors and omissions, and site conditions. The investigation then concluded that the main root causes were related to variation orders, delays by the owner, material changes, and variations in quantities (Zaneldin 2020). Further investigation into the International Federation of Consulting Engineers (FIDIC) contract conditions to determine the priority of the claim and dispute factors in an overseas construction project in Korea revealed 30 claim risk factors, of which failure to examine contract conditions at the time of tender was ranked highest (Choi and Kim 2016). Other causes that were identified in common as contributors to rework were acceleration, unrealistic contract, site management, improper planning, inadequate contractor experience, mistakes during construction, improper construction methods, quality assurance and control, material quality and shortage, change orders, mistakes and discrepancies in the contract document, lack of communication, weather conditions, site conditions, and coordination problems (Kim and Skibniewski 2020).

Rework root causes are variables that facilitate the occurrence of claims. These variables may appear as an event, a chain of factors, or triggers resulting in rework in the project. The emergence of rework root causes at all project stages is a possibility that cannot be ignored. Previous researchers have identified various root causes of rework. The study carried out by Liu et al. (2020) revealed that most rework costs are generated by three factors: contractor field management, design management, and client management. It also categorized 37 contributing subcauses of rework under 11 significant factors in China. Ranking of the subcauses of rework in this study showed that lack of communication between client and project parties has the highest impact on rework cost followed by design mistakes, contradictory instructions, ineligible techniques, and poor site conditions. Factors identified by Hwang et al. (2019) included client changes, design errors and omissions, design changes, contractor error and omissions, contractor changes, vendor errors and omissions, vendor changes, and transportation errors. These factors as the sources of rework were examined to measure the impacts of building information modeling (BIM) implementation in construction projects in Singapore. The omission and planning, change issues, funding and communication issues, poor workers, and resource control are the principal rework risk triggers in Nigerian construction projects that cause rework (Eze et al. 2018a).

Mahamid (2016a), in a survey conducted among residential buildings in Palestine, found that poor communication of client with contractors and consultant, poor-quality material use, and poor site management are the most severe rework causes that need attention. Other studies also confirmed that the client significantly 
contributes to most rework projects (Hwang et al. 2014). The study of the client rework-related factors in Singapore revealed that the client usually replaces material, changes project plans and scope, and is involved in low-level decision-making processes. Using substandard services, defects under the grouping of related technical factors, lack of support for site management, lack of commitment in the quality management-related group, disturbance of personal planning, carelessness, lack of skill, and inexperienced staff under the human resources-related factors are known as the highest contributors to rework occurrence in the study done by Oyewobi and Ogunsemi (2010). According to Enshassi et al. (2017), attempts to defraud, competitive pressure, ineffective management, and schedule pressure are the main causes of rework in the Gaza Strip that influence the productivity of construction projects. The most commonly used rework factors and their root causes can be found in the studies done by Palaneeswaran et al. (2008) and Love et al. (2009) categorized under four headings: client, contractor, site management, and subcontractor groups. They include changes, errors, omissions, lack of allocating funds, low contract fee, ineffective use of quality management, poor technology use, and incomplete design at tender time, leading to poor contract documentation. Some other factors and causes of rework related to external sources or environmental aspects have also been identified, including political issues, economic situations, and weather conditions (Mahamid 2016b; Enshassi et al. 2017).

The characteristics of the project are altered by activation of rework root causes. Thus, the project results do not meet the contract or the client's requirements. According to Al-Janabi et al. (2020), poor contract management could result in ambiguity in the contract documentation. Initially, such ambiguity is due to the poorly defined scope of the project by the client. Mistakes in the contract documentation create errors during the construction process that will ultimately end with change orders, claims, and rework. Thus, the procurement stage of the project needs more investigation to minimize such problems. Further studying of the effects of procurement on rework in construction projects has also been recommended (Anjum and Azam 2019). This research aims to identify the root causes of rework through a comprehensive review of the literature and examine their influence on contractual claims by conducting a questionnaire survey. The identified root causes provide a basis to understand the potential problems in rework occurrence that lead to claims and other contractual issues. Thus, it would help project organizations to control rework's adverse effects such as disputes by addressing identified causes in the contract documents.

\section{Methodology}

For this study, a mixed method of literature and survey was used to cluster and rank rework causes that generate claims using relative importance index (RII) analysis. The study followed a comprehensive literature review to identify the causes of rework, and then a questionnaire approach to collect data was carried out. The initial strategy was based on the analysis of implemented theories for meeting the sources of rework through the literature. The survey then comprised structured questions, including 37 identified rework causes collected from previous studies for further investigation. The employed strategy was completed by gathering professionals' opinions to evaluate the contractual claims during rework circumstances. The second phase was designed to assess contract documents in the presence of ework causes among practitioners in New Zealand construction companies. Before sending questions out to collect data, a pilot study was conducted to verify that questions are reliable, answerable, and designed appropriately to align with the research objectives.

The adopted framework of 4-level methodology to gain insight into the relationship between rework causes and contractual claims in New Zealand construction contracts is presented in Fig. 1. After preanalysis of identified rework causes and categorizing them into five groups of factors, the questionnaire survey using a 5-point Likert scale was distributed to the targeted participants. Finally, descriptive statistics were adopted for participants' demographic information, and a relative importance index was performed for ranking the causes of rework. The methodology's outline simply follows the sequences as described hereafter.

\section{Literature Review and Content Analysis of the Literature}

A 4-step systematic literature review was carried out. In this stage, rework-related articles were identified to determine the possible causes and their classification models. The comprehensive literature review followed four main steps: (1) defining a strategy search by choosing the keyword of rework in the title of papers in the field of construction between 1990 and 2020, (2) refining the identified papers by applying some exclusion and inclusions to find more precise articles according to the scope of the study, (3) quality assessment of the remaining papers by scanning the titles and reviewing the abstracts, and (4) extraction data from the final shortlisted papers using a Microsoft Excel file. Similarity checking to prevent

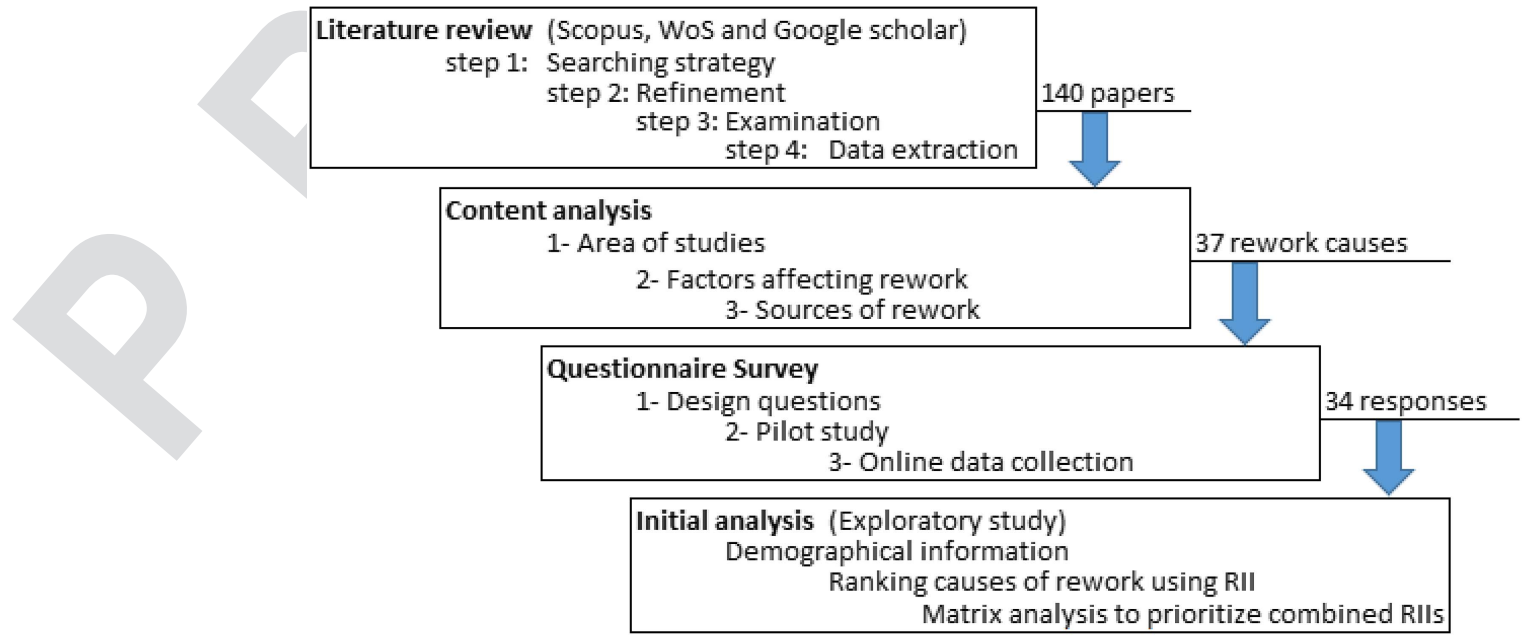

Fig. 1. Applied methodology. 
duplications in published papers and identified rework causes was also carried out. Three search engines were employed for retrieving relevant journals and conference papers. The shortlist of relevant articles was prepared after screening the full text of the selected papers. This stage finally concluded with a list of rework root causes disseminated throughout the project's life cycle.

\section{Questionnaire Design and Pilot Study}

In reference to Table 1, a total of 37 retrieved root causes of rework from the literature were selected to be used in the preliminary questionnaire. Following the literature's concept, similar causes of rework were grouped to construct rework factors under five broad headings: process, human resources, material and equipment, technical, and general/external-related factors. Because one purpose of this paper is to explore the significant causes to be included in the next research step, it was decided to use an exploratory survey research design. A well-structured questionnaire to collect data from the causes leading to contractual claims was designed. The questionnaire was based on the 5-point Likert scale from strongly disagree (1) to strongly agree (5) to measure the influence of each cause on claims. The survey involving the use of these structured questions covers the quantitative part of the research. A pilot study verified the questionnaire and ensured that the questions are appropriate for research purposes. The questionnaire was tested with four experts, two from the academic field and two from industry. The academic experts reviewed the fluency and clarity of the questions in line with the study's objectives and confirmed the simplicity and precise language (Gunduz and Elsherbeny 2020). Also, questions were controlled because they need to be easy to answer (Eze et al. 2018a). Two industry experts were interviewed, and a draft copy with a cover letter was emailed to obtain their comments about the content validity. They gave comments to modify questions based on the industry's expectations. The selection criteria of pilot study participants were mainly based on their expertise and years of experience related to the research subject. Each interviewee had more than 30 years of experience in contracting and construction management. According to their advice, the questionnaire was slightly modified to improve the quality by merging the same items from different project stages, because the general conditions of the contract cover the entire life cycle of a project. The pilot study ensured that all questions were sufficiently defined without the possibility of misunderstanding arising (Ye et al. 2015). The survey included two lead questions as follows, with 37 causes of rework listed under each question. Question 1 determined which causes create claims and Question 2 established which causes have not been addressed in the general conditions of the standard from of contract in New Zealand:

1. To what extent do you agree that the following rework root causes lead to claims and other contractual issues?

2. To what extent do you agree that the conditions of contract NZS 3910:2013 adequately address the following rework root causes?

\section{Conducting Survey}

The finalized questionnaire was developed as an instrument for data collection in two separate parts. The survey was started with general questions to collect demographic information of participants such as experience, project value, type of organization, and position. Before moving to the next part of the survey, participants needed to advise whether they are from the client or contractor side of the contract. Then they were given the developed list from the literature that contains 37 rework root causes. This part asks to what extent participants agree that rework causes lead to claims and other contractual issues. It explores the relationship between claims and rework causes. Respondents were then asked to answer to what extent they agree that the contract conditions adequately addressed each of the causes listed in the questionnaire. A 5-point Likert scale was used to measure and quantify each cause's importance. The questionnaire was agreed to be used online, and the survey questions were placed on Qualtrics software and distributed electronically to draw the professionals' views on the construction industry. The target population for the main research was a combination of clients and contractors working on civil and infrastructure projects, certified builders, architectural consultant firms, and other organizations that generally use the standard form of contract in their projects.

A list of 173 firms was provided for the first round of questionnaire distribution by checking the Infrastructure New Zealand and Association of Consulting and Engineering in New Zealand (ACENZ) authorities. The list comprised 133 architects and consultant firms and 40 civil and construction contractors. The questionnaire link was emailed to the targeted firms with a cover letter explaining the research aims. All invited firms participating in the survey were asked to complete the questionnaire if they had experience of contracting management. The invitation emails introduced the survey and requested participants to answer the survey question only if they have experience using the standard form NZS 3910 contract conditions. As a result, all respondents had enough understanding of the claims process under construction contracts. This point brings more validity and reliability to the collected data (Kisi et al. 2020).

Because the research process was completed later by conducting an interview, it was necessary to analyze the primarily collected data for designing the interview questions. The Qualtrics software showed the completed survey with 46 participants through 1.5 months, a response rate of about $26.58 \%$. The achieved rate was suitable for starting the initial analysis on ranking rework causes to design the interview questions. According to Yap et al. (2017), a sample size between 30 and 500 is adequate for initial analysis in most conducted research. Therefore, the collected data from the completed questionnaire by 46 respondents were extracted to SPSS to perform the required analysis. A more detailed review of the completed survey revealed that only 34 responses were properly filled in with all the required questions. The remaining 12 responses with incomplete answers were considered invalid and discarded from the list. Fig. 2 illustrates the respondents' distribution based on the type of organization and their response rate. The participants' cumulative response rate was about $20 \%$ based on 173 distributed and 34 submitted/returned questionnaires. This rate is close to the acceptable normal range for conducting research analysis in construction management (Hwang and Yang 2014; Hwang et al. 2016). Conducting research analysis on the basis of the same number of responses and less can also be seen in the literature (Banwo et al. 2015; Oyewobi et al. 2016; Lessing et al. 2017). The responses comprised 21 on the client side of the contract and 13 on the contractor side, showing relatively sufficient coverage of both contract sides for an acceptable result.

\section{Data Analysis and Results}

This paper presents a statistical analysis using an RII to evaluate collected data and rank the causes of rework for both study's objectives. A 5-point Likert scale was used to measure the frequency of each rework cause and then provide the priority list of causes. According to Zaneldin (2020), collected data from a construction research survey using a Likert scale are frequently analyzed through the RII method. Therefore, the RII method was employed in this 
Table 1. Root causes of rework identified from the literature

$\mathrm{T} 1: 2$

Changes, modification, and revisions in design/construction changes

T1:4 2 Incomplete design, any omission in the design or construction process

T1:5 $3 \quad$ Error in design, drawings, and specifications/error in construction $\begin{array}{ll}\text { T1:6 } 4 & \begin{array}{l}\text { Improper contractor and } \\ \text { subcontractor selection }\end{array}\end{array}$

T1:7 $5 \quad$ Inadequate procurement methods/poor contract execution

Lack of document control

T1:8 $6 \quad$ Lack of document control

Insufficient skilled level manpower

Lack of experience and personal expertise in design and construction

Poor knowledge of team member, lack of education and training

\begin{tabular}{|c|c|c|}
\hline $\mathrm{T} 1: 13$ & 10 & $\begin{array}{l}\text { Poor workmanship approach and } \\
\text { inappropriate personal attitude }\end{array}$ \\
\hline $\mathrm{T} 1: 14$ & 11 & $\begin{array}{l}\text { Labor reallocation, alteration, and } \\
\text { staff turnover }\end{array}$ \\
\hline $\mathrm{T} 1: 15$ & 12 & $\begin{array}{l}\text { Inadequate manpower to complete } \\
\text { the task }\end{array}$ \\
\hline $\mathrm{T} 1: 16$ & 13 & $\begin{array}{l}\text { Lack of employee motivation and } \\
\text { rewards, carelessness }\end{array}$ \\
\hline $\mathrm{T} 1: 17$ & 14 & $\begin{array}{l}\text { Absence of job security and other } \\
\text { safety rules }\end{array}$ \\
\hline $\mathrm{T} 1: 18$ & 15 & Inadequate supervision staff \\
\hline $\mathrm{T} 1: 19$ & 16 & Conflict of interest \\
\hline
\end{tabular}

Process

Josephson et al. (2002), Love and Smith (2003), Robinson et al. (2004), Palaneeswarane et al. (2005), Palaneeswaran (2006), Palaneeswaran et al. (2008), Love et al. (2009), Oyewobi and Ogunsemi (2010), Love et al. (2010), Zhang et al. (2012), Aiyetan (2013), Hwang et al. (2014), Ye et al. (2015), Miri and Khaksefidi (2015), Aiyetan and Das (2015), Mahamid (2016a), Shah et al. (2016), Oyewobi et al. (2016), Wilson and Odesola (2017), Enshassi et al. (2017), Ndwandwa et al. (2017), Eze et al. (2018a, b), Trach et al. (2019), Hwang et al. (2019), Liu et al. (2020), Mahamid (2020)

Josephson et al. (2002), Love and Smith (2003), Robinson et al. (2004), Palaneeswarane et al. (2005), Palaneeswaran (2006), Palaneeswaran et al. (2008), Love et al. (2009), Oyewobi and Ogunsemi (2010), Love et al. (2010), Zhang et al. (2012), Aiyetan (2013), Palaneeswaran et al. (2014), Ye et al. (2015), Ajayi and Oyeyipo (2015), Mahamid (2016a), Oyewobi et al. (2016), Wilson and Odesola (2017), Enshassi et al. (2017), Ndwandwa et al. (2017), Ajayi (2017), Eze et al. (2018a, b), Trach et al. (2019), Hwang et al. (2019), Mahamid (2020)

Josephson et al. (2002), Love and Smith (2003), Robinson et al. (2004), Palaneeswarane et al. (2005), Palaneeswaran (2006), Palaneeswaran et al. (2008), Love et al. (2009), Oyewobi and Ogunsemi (2010), Love et al. (2010), Zhang et al. (2012), Aiyetan (2013), Palaneeswaran et al. (2014), Ye et al. (2015), Miri and Khaksefidi (2015), Ajayi and Oyeyipo (2015), Aiyetan and Das (2015), Mahamid (2016a), Oyewobi et al. (2016), Wilson and Odesola (2017), Enshassi et al. (2017), Ndwandwa et al. (2017), Eze et al. (2018a, b), Trach et al. (2019), Hwang et al. (2019), Mahamid (2020)

Palaneeswarane et al. (2005), Palaneeswaran (2006), Palaneeswaran et al. (2008), Aiyetan (2013), Palaneeswaran et al. (2014), Mahamid (2016a), Ahmed and Naik (2016), Oyewobi et al. (2016), Ndwandwa et al. (2017), Mahamid (2020)

Oyewobi and Ogunsemi (2010), Aiyetan (2013), Ye et al. (2015), Oyewobi et al. (2016), Wilson and Odesola (2017), Enshassi et al. (2017), Hwang et al. (2019)

Robinson et al. (2004), Zhang et al. (2012), Forcada et al. (2014), Aiyetan and Das (2015), Oyewobi et al. (2016), Wilson and Odesola (2017), Safapour et al. (2019)

\section{Human resources}

Love and Smith (2003), Robinson et al. (2004), Palaneeswaran (2006), Palaneeswaran et al. (2008), Oyewobi and Ogunsemi (2010), Love et al. (2010), Zhang et al. (2012), Palaneeswaran et al. (2014), Forcada et al. (2014), Miri and Khaksefidi (2015), Ajayi and Oyeyipo (2015), Mahamid (2016a), Shah et al. (2016), Ahmed and Naik (2016), Oyewobi et al. (2016), Wilson and Odesola (2017), Enshassi et al. (2017), Ndwandwa et al. (2017), Ajayi (2017), Yap et al. (2017), Eze et al. (2018a, b), Trach et al. (2019), Safapour et al. (2019), Mahamid (2020)

Love and Smith (2003), Palaneeswaran (2006), Palaneeswaran et al. (2008), Love et al. (2009), Oyewobi and Ogunsemi (2010), Love et al. (2010), Zhang et al. (2012), Aiyetan (2013), Palaneeswaran et al. (2014), Forcada et al. (2014), Miri and Khaksefidi (2015), Ajayi and Oyeyipo (2015), Aiyetan and Das (2015), Mahamid (2016), Ahmed and Naik (2016), Oyewobi et al. (2016), Wilson and Odesola (2017), Ndwandwa et al. (2017), Ajayi (2017), Eze et al. (2018a, b), Trach et al. (2019), Safapour et al. (2019)

Love and Smith (2003), Palaneeswaran (2006), Palaneeswaran et al. (2008), Love et al. (2009), Oyewobi and Ogunsemi (2010), Love et al. (2010), Zhang et al. (2012), Palaneeswaran et al. (2014), Forcada et al. (2014), Miri and Khaksefidi (2015), Ajayi and Oyeyipo (2015), Mahamid (2016a), Shah et al. (2016), Ahmed and Naik (2016), Oyewobi et al. (2016), Wilson and Odesola (2017), Enshassi et al. (2017), Ajayi (2017), Eze et al. (2018a, b), Trach et al. (2019), Hwang et al. (2019), Safapour et al. (2019)

Josephson et al. (2002), Palaneeswaran (2006), Palaneeswaran et al. (2008), Oyewobi and Ogunsemi (2010), Zhang et al. (2012), Miri and Khaksefidi (2015), Ajayi and Oyeyipo (2015), Aiyetan and Das (2015), Mahamid (2016), Shah et al. (2016), Enshassi et al. (2017), Ajayi (2017), Eze et al. (2018a, b), Trach et al. (2019), Hwang et al. (2019), Mahamid (2020) Love and Smith (2003), Palaneeswarane et al. (2005), Palaneeswaran (2006), Palaneeswaran et al. (2008), Love et al. (2009), Oyewobi and Ogunsemi (2010), Love et al. (2010), Palaneeswaran et al. (2014), Miri and Khaksefidi (2015), Ajayi and Oyeyipo (2015), Mahamid (2016), Oyewobi et al. (2016), Ajayi (2017), Eze et al. (2018a, b), Mahamid (2020), Salihu and Babarinde (2020)

Love and Smith (2003), Palaneeswaran (2006), Palaneeswaran et al. (2008), Love et al. (2009), Oyewobi and Ogunsemi (2010), Love et al. (2010), Palaneeswaran et al. (2014), Miri and Khaksefidi (2015), Ajayi and Oyeyipo (2015), Ndwandwa et al. (2017), Ajayi (2017), Hwang et al. (2019), Safapour et al. (2019)

Oyewobi and Ogunsemi (2010), Zhang et al. (2012), Mahamid (2016), Shah et al. (2016), Oyewobi et al. (2016), Enshassi et al. (2017), Safapour et al. (2019), Mahamid (2020) Oyewobi and Ogunsemi (2010), Shah et al. (2016), Oyewobi et al. (2016), Enshassi et al. (2017), Safapour et al. (2019)

Robinson et al. (2004), Love et al. (2010), Forcada et al. (2014), Mahamid (2016), Yap et al. (2017) Aiyetan (2013), Shah et al. (2016), Enshassi et al. (2017), Hwang et al. (2019) 
Table 1. (Continued.)

Group Rework root causes

Poor-quality material or substandard products/prefabrication errors

T1:23 $18 \quad$ Defective materials, nonadherence to material specifications

T1:24 $19 \quad$ Inefficient equipment uses or altered material

Replacement or misplacement of material and equipment

Untimely deliveries of material and equipment

Poor communication system for coordinating between members

Ineffective use of quality management practices/deviation due to poor monitoring

Inadequate planning and poor scheduling of workload

Poor project documents, unclear instructions, poor contract documents

Conflicting and incomplete information

Inefficient management process, poor site management practice

Poor technology application and lack of information technology use
Material and equipment

Josephson et al. (2002), Love and Smith (2003), Palaneeswarane et al. (2005), Palaneeswaran (2006), Palaneeswaran et al. (2008), Oyewobi and Ogunsemi (2010), Love et al. (2010), Aiyetan (2013), Palaneeswaran et al. (2014), Ye et al. (2015), Miri and Khaksefidi (2015), Ajayi and Oyeyipo (2015), Aiyetan and Das (2015), Mahamid (2016), Shah et al. (2016), Ndwandwa et al. (2017), Ajayi (2017), Hwang et al. (2019), Safapour et al. (2019), Liu et al. (2020) Josephson et al. (2002), Robinson et al. (2004), Oyewobi and Ogunsemi (2010), Zhang et al. (2012), Aiyetan (2013), Hwang et al. (2014), Forcada et al. (2014), Ye et al. (2015), Aiyetan and Das (2015), Shah et al. (2016), Enshassi et al. (2017), Ndwandwa et al. (2017), Yap et al. (2017), Hwang et al. (2019), Safapour et al. (2019)

Josephson et al. (2002), Oyewobi and Ogunsemi (2010), Ye et al. (2015), Mahamid (2016), Shah et al. (2016), Enshassi et al. (2017), Ndwandwa et al. (2017), Yap et al. (2017), Liu et al. (2020), Mahamid (2020)

Josephson et al. (2002), Oyewobi and Ogunsemi (2010), Forcada et al. (2014), Ye et al. (2015), Shah et al. (2016), Enshassi et al. (2017), Eze et al. (2018a, b), Trach et al. (2019), Hwang et al. (2019)

Josephson et al. (2002), Robinson et al. (2004), Oyewobi and Ogunsemi (2010), Zhang et al. (2012), Shah et al. (2016), Enshassi et al. (2017), Ndwandwa et al. (2017)

Technical

Josephson et al. (2002), Love and Smith (2003), Palaneeswaran (2006), Palaneeswaran et al. (2008), Love et al. (2009), Oyewobi and Ogunsemi (2010), Love et al. (2010), Zhang et al. (2012), Aiyetan (2013), Palaneeswaran et al. (2014), Forcada et al. (2014), Ye et al. (2015), Miri and Khaksefidi (2015), Ajayi and Oyeyipo (2015), Aiyetan and Das (2015), Mahamid (2016), Ahmed and Naik (2016), Oyewobi et al. (2016), Wilson and Odesola (2017), Enshassi et al. (2017), Ndwandwa et al. (2017), Ajayi (2017), Yap et al. (2017), Eze et al. (2018a, b), Trach et al. (2019), Hwang et al. (2019), Safapour et al. (2019), Liu et al. (2020), Mahamid (2020), Salihu and Babarinde (2020)

Love and Smith (2003), Robinson et al. (2004), Palaneeswarane et al. (2005), Palaneeswaran (2006), Palaneeswaran et al. (2008), Love et al. (2009), Oyewobi and Ogunsemi (2010), Love et al. (2010), Zhang et al. (2012), Aiyetan (2013), Palaneeswaran et al. (2014), Forcada et al. (2014), Ye et al. (2015), Miri and Khaksefidi (2015), Aiyetan and Das (2015), Mahamid (2016a), Shah et al. (2016), Oyewobi et al. (2016), Wilson and Odesola (2017), Enshassi et al. (2017), Ndwandwa et al. (2017), Yap et al. (2017), Eze et al. (2018a, b), Hwang et al. (2019), Safapour et al. (2019), Liu et al. (2020), Salihu and Babarinde (2020)

Josephson et al. (2002), Love and Smith (2003), Robinson et al. (2004), Palaneeswarane et al. (2005), Palaneeswaran (2006), Palaneeswaran et al. (2008), Love et al. (2009), Oyewobi and Ogunsemi (2010), Love et al. (2010), Zhang et al. (2012), Aiyetan (2013), Palaneeswaran et al. (2014), Forcada et al. (2014), Miri and Khaksefidi (2015), Ajayi and Oyeyipo (2015), Aiyetan and Das (2015), Mahamid (2016a), Shah et al. (2016), Oyewobi et al. (2016), Wilson and Odesola (2017), Enshassi et al. (2017), Ndwandwa et al. (2017), Ajayi (2017), Eze et al. (2018a, b), Trach et al. (2019), Liu et al. (2020), Salihu and Babarinde (2020)

Love and Smith (2003), Palaneeswarane et al. (2005), Palaneeswaran (2006), Palaneeswaran et al. (2008), Love et al. (2009), Oyewobi and Ogunsemi (2010), Love et al. (2010), Zhang et al. (2012), Aiyetan (2013), Palaneeswaran et al. (2014), Ye et al. (2015), Miri and Khaksefidi (2015), Ajayi and Oyeyipo (2015), Aiyetan and Das (2015), Mahamid (2016a), Shah et al. (2016), Oyewobi et al. (2016), Wilson and Odesola (2017), Enshassi et al. (2017), Ndwandwa et al. (2017), Ajayi (2017), Yap et al. (2017), Eze et al. (2018a, b), Trach et al. (2019), Hwang et al. (2019), Liu et al. (2020)

Josephson et al. (2002), Robinson et al. (2004), Palaneeswaran (2006), Palaneeswaran et al. (2008), Oyewobi and Ogunsemi (2010), Love et al. (2010), Aiyetan (2013), Forcada et al. (2014), Ye et al. (2015), Miri and Khaksefidi (2015), Ajayi and Oyeyipo (2015), Aiyetan and Das (2015), Mahamid (2016a), Shah et al. (2016), Oyewobi et al. (2016), Wilson and Odesola (2017), Enshassi et al. (2017), Ndwandwa et al. (2017), Ajayi (2017), Eze et al. (2018a, b), Trach et al. (2019), Liu et al. (2020), Salihu and Babarinde (2020)

Robinson et al. (2004), Oyewobi and Ogunsemi (2010), Zhang et al. (2012), Aiyetan (2013), Palaneeswaran et al. (2014), Hwang et al. (2014), Forcada et al. (2014), Ye et al. (2015), Miri and Khaksefidi (2015), Ajayi and Oyeyipo (2015), Aiyetan and Das (2015), Mahamid (2016), Oyewobi et al. (2016), Enshassi et al. (2017), Ndwandwa et al. (2017), Ajayi (2017), Yap et al. (2017), Eze et al. (2018a, b), Hwang et al. (2019), Safapour et al. (2019), Liu et al. (2020), Mahamid (2020)

Love and Smith (2003), Palaneeswarane et al. (2005), Palaneeswaran (2006), Palaneeswaran et al. (2008), Love et al. (2009), Oyewobi and Ogunsemi (2010), Love et al. (2010), Aiyetan (2013), Palaneeswaran et al. (2014), Ye et al. (2015), Miri and Khaksefidi (2015), Ajayi and Oyeyipo (2015), Aiyetan and Das (2015), Wilson and Odesola (2017), Enshassi et al. (2017), Ajayi (2017), Yap et al. (2017), Eze et al. (2018a, b), Trach et al. (2019), Salihu and Babarinde (2020) 
Table 1. (Continued.)

Group Rework root causes

Covered by references

Financial issues such as lack of funding, low contract or payment fee, delay in payment, and cost pressure

Time pressure, schedule acceleration to finish the task, insufficient time to prepare contract documentation

T1:39 $31 \quad \begin{aligned} & \text { Damage/defects/deviations in the } \\ & \text { product due to poor handling and } \\ & \text { safety }\end{aligned}$

T1:40 $32 \quad$ Environmental conditions, poor site conditions

T1:41 $33 \quad$ Lack of client involvement

Lack of constructability

Governmental regulations/changes and policies

Unclear line of authority

\section{General/external}

Love and Smith (2003), Robinson et al. (2004), Palaneeswaran (2006), Palaneeswaran et al. (2008), Love et al. (2009), Oyewobi and Ogunsemi (2010), Love et al. (2010), Aiyetan (2013), Palaneeswaran et al. (2014), Hwang et al. (2014), Ye et al. (2015), Miri and Khaksefidi (2015), Ajayi and Oyeyipo (2015), Aiyetan and Das (2015), Mahamid (2016a), Shah et al. (2016), Ahmed and Naik (2016), Oyewobi et al. (2016), Enshassi et al. (2017), Ndwandwa et al. (2017), Ajayi (2017), Eze et al. (2018a, b), Trach et al. (2019), Hwang et al. (2019), Safapour et al. (2019), Liu et al. (2020)

Love and Smith (2003), Robinson et al. (2004), Palaneeswaran (2006), Palaneeswaran et al. (2008), Love et al. (2009), Oyewobi and Ogunsemi (2010), Love et al. (2010), Aiyetan (2013), Palaneeswaran et al. (2014), Forcada et al. (2014), Ye et al. (2015), Miri and Khaksefidi (2015), Ajayi and Oyeyipo (2015), Aiyetan and Das (2015), Mahamid (2016a), Shah et al. (2016), Ahmed and Naik (2016), Oyewobi et al. (2016), Wilson and Odesola (2017), Enshassi et al. (2017), Ndwandwa et al. (2017), Ajayi (2017), Yap et al. (2017), Eze et al. (2018a, b), Trach et al. (2019), Salihu and Babarinde (2020)

Love and Smith (2003), Palaneeswarane et al. (2005), Palaneeswaran (2006), Palaneeswaran et al. (2008), Love et al. (2009), Oyewobi and Ogunsemi (2010), Love et al. (2010), Aiyetan (2013), Palaneeswaran et al. (2014), Ye et al. (2015), Miri and Khaksefidi (2015), Ajayi and Oyeyipo (2015), Aiyetan and Das (2015), Mahamid (2016), Oyewobi et al. (2016), Ajayi (2017), Eze et al. (2018a, b), Hwang et al. (2019), Mahamid (2020)

Palaneeswaran (2006), Palaneeswaran et al. (2008), Oyewobi and Ogunsemi (2010), Ye et al. (2015), Ajayi and Oyeyipo (2015), Mahamid (2016a), Shah et al. (2016), Oyewobi et al. (2016), Enshassi et al. (2017), Ajayi (2017), Yap et al. (2017), Eze et al. (2018a, b), Hwang et al. (2019), Safapour et al. (2019), Liu et al. (2020), Mahamid (2020)

Love and Smith (2003), Palaneeswaran (2006), Palaneeswaran et al. (2008), Love et al. (2009), Oyewobi and Ogunsemi (2010), Love et al. (2010), Aiyetan (2013), Palaneeswaran et al. (2014), Miri and Khaksefidi (2015), Ajayi and Oyeyipo (2015), Mahamid (2016), Ahmed and Naik (2016), Ndwandwa et al. (2017), Ajayi (2017), Eze et al. (2018a, b), Trach et al. (2019) Robinson et al. (2004), Palaneeswaran (2006), Palaneeswaran et al. (2008), Ye et al. (2015), Ajayi and Oyeyipo (2015), Shah et al. (2016), Wilson and Odesola (2017), Enshassi et al. (2017), Ajayi (2017), Eze et al. (2018a, b), Hwang et al. (2019)

Ye et al. (2015), Shah et al. (2016), Enshassi et al. (2017), Hwang et al. (2019)

Shah et al. (2016), Enshassi et al. (2017)

Oyewobi and Ogunsemi (2010), Ye et al. (2015)
27 sources

Total of valid questions

Total of invalid questions

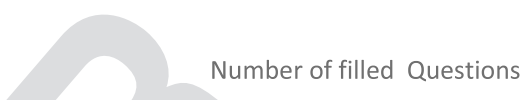

Number of filled Questions

Number of Distributed Questions

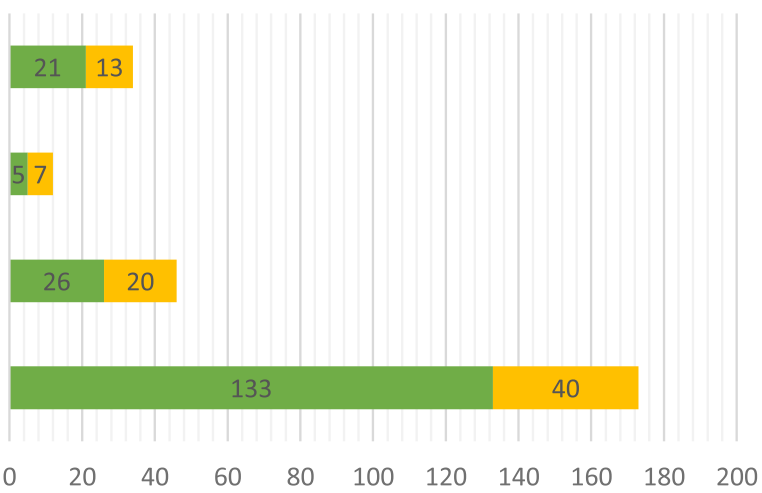

Fig. 2. Distribution of respondents and organizations.

paper to measure the importance of rework causes. The RII technique facilitates comparative analysis, depicts the most contributing elements of management, and helps planners allocate resources better (Alaghbari et al. 2018). This method determines the importance level of each cause listed in the questionnaire and then ranks all causes. The RII result identifies the most significant rework causes that lead to contractual claims and gives the severity indication for each cause. The list of 37 identified rework root causes are the variables of this research that affect claim and other contractual issues in construction contracts. The ranked causes of rework then were transferred into a matrix through a combination of the relative importance index of each cause in relation to both objectives of the study. The matrix prioritizes rework causes at different levels of importance for further study. 


\section{Results of the Systematic Literature Review}

To identify the cause of rework, 35 articles out of the initial 140 documents were relevant to the research scope. Content analysis of the relevant papers resulted in the identifying rework causes as listed in Table 1, which are classified into five groups as the most common rework causes. Table 1 also shows the total number of citations within the reviewed papers in this study's scope. These causes can result from either the nature of construction or the other imposed determinants such as human attributes, procurement approaches, external factors, and supporting activities. In line with the previous research studies on the classification of rework causes, the 37 identified items are clustered into the generic sources for interpretation and further discussion concerning the contract. Some of the causes are process based and ignoring them stops the progression of work. This group included the causes of rework that mostly occur during the project's main activities (Zhang et al. 2012). Changes, errors, omissions, and incomplete or faulty processes can be categorized under process-related factors. Knowledge, skills, experiences, motivations, and other similar characteristics are human attributes and can be clustered in one group of causes. Some causes are related to the provided material or used equipment directly affecting the construction project's outcomes. The causes linked to supplying the required material and equipment for the project are categorized under material/equipment-related factors (Robinson et al. 2004). Other causes are related to the activities that provide support services to the main process, such as quality control for monitoring, employing technology, communication means, planning, and scheduling for controlling projects. All these causes are clustered under technicalrelated factors (Oyewobi and Ogunsemi 2010). The last group of causes consisting of nine items is generally linked to the external sources and are listed in no particular order.

\section{Analysis and Survey Result}

The detailed demographics of respondents are given in Table 2. As summarized in Table 2, demographic data analysis revealed that the consultants' companies contributed the most to the survey with the frequency of 19 out of 34 responses, equal to $55.88 \%$. About $61.76 \%$ of the participants were from the client side, and the remaining $38.23 \%$ filled their survey questions from the contractor

Table 2. Demographic characteristics of respondents

\begin{tabular}{lccr}
\hline Profile & Classification & Frequency & Percent \\
\hline Organizational type & Client & 2 & 5.88 \\
& Consultant & 19 & 55.88 \\
& Contractor & 11 & 32.35 \\
& Subcontractor & 2 & 5.88 \\
Role of participants & Project director & 11 & 32.35 \\
& Project manager & 6 & 17.64 \\
& Contract manager & 1 & 2.94 \\
& Commercial manager & 3 & 8.82 \\
& Quantity surveyor & 5 & 14.70 \\
& Others & 8 & 23.52 \\
Years of experience & Less than 5 years & 0 & 0 \\
& 6-10 years & 5 & 14.70 \\
& $11-15$ years & 2 & 5.88 \\
& 16-20 years & 3 & 8.82 \\
& 21-25 years & 4 & 11.76 \\
& Over 25 years & 20 & 58.82 \\
& Client & 21 & 61.76 \\
& Contractor & 13 & 38.23 \\
\hline
\end{tabular}

side. Therefore, the importance index of rework causes comprises enough responses from both sides of the contract. In terms of the role of participants, the highest percentage is project directors with $32 \%$. The respondents' other positions that show $23 \%$ include two CEOs, three project advisors, one regional manager, one contract engineer, and one building surveyor. Most respondents had more than 25 years of experience in the construction field, with a rate of $58.82 \%$. This rate verifies that the analysis result is authentic based on the given information from an experienced sample. Regarding the years of experience in contracting management, all participants were from the construction sector, and the highest percentage belonged to the group having more than 10 years' experience, at $76 \%$, compared to the other groups. The high percentage of this group with more than 10 years of experience in contracting management strengthens the collected data's reliability and results.

\section{Internal Reliability of the Questionnaire}

The $T$-test technique was used to ensure that the sample size, including two categories of 21 clients and 13 contractors, is adequate to deliver a trustworthy finding. This test is used to find discrepancies between different groups of respondents in answering the questions. The results confirmed that the $p$-values of only three causes out of 37 regarding Objective 1 were less than 0.05 as can be seen in Table 3 . In other words, there are no significant differences between the two groups of client and contractor for the majority of variables, and consequently, the result of the initial analysis is meaningful due to minimal inconsistencies (Lee et al. 2020). The SPSS result also showed a $p$-value for all 37 causes in Objective 2 is more than 0.05 . Thus, the initial analysis result is satisfactory for conducting the next research step.

The validity of the responses was also verified through a reliability test. Before data analysis, the reliability of the questions needs to be examined. For this purpose, the internal consistency of the variables among two different respondent groups, client and contractor, was measured using the Cronbach alpha test. Because a Likert scale was used to measure the study variables, the questionnaire's reliability can be checked through the Cronbach alpha test. The result of this test with the figure greater than 0.7 shows higher internal consistency based on the participants' responses and proves the reliability of the questions (Gamil and Rahman 2020; Gunduz and Elsherbeny 2020). The Cronbach alpha test results among all 37 rework causes were in a range of 0.949 to 0.953 in Objective 1 and equal to 0.968 in Objective 2. This result proves the reliability of the questions. Thus, the data's internal consistency received high appraisal, and the collected data were reliable for performing further analysis. IBM SPSS version 26 software was used for all analysis in this paper.

The relative importance index of each rework cause is presented in Table 4 and the result of implementing RII for each group of factors is presented in Table 5. It shows that process-related factors

Table 3. Result of $T$-test for the causes of rework

\begin{tabular}{lcccc}
\hline Rework cause variable & Group & $N$ & Mean & $\begin{array}{c}p \text {-value } \\
\text { (significance) }\end{array}$ \\
\hline Inadequate supervision staff & Client side & 21 & 3.76 & 0.003 \\
& Contractor side & 13 & 4.00 & - \\
Insufficient skilled level & Client side & 21 & 3.62 & 0.011 \\
manpower & Contractor side & 13 & 4.31 & - \\
Time pressure, schedule & Client side & 21 & 3.90 & 0.006 \\
acceleration to finish the task, & Contractor side & 13 & 3.54 & - \\
$\begin{array}{l}\text { insufficient time to prepare } \\
\text { contract documentation }\end{array}$ & & & & \\
\hline
\end{tabular}

contract documentation
75
76

87

5 7 8 07

3
1
2
3
4
5
6
7
3
9
0
1
2
3

77
78

9
0

32
33 5

89
90

1

4 00 2 03
04 5 
Table 4. Relative importance index of rework root causes for objectives of the study on general conditions of NZS 3910

\begin{tabular}{|c|c|c|c|c|c|c|c|}
\hline \multirow[b]{2}{*}{ Group } & \multirow[b]{2}{*}{ Rework root cause } & \multicolumn{3}{|c|}{ Objective 1} & \multicolumn{3}{|c|}{ Objective 2} \\
\hline & & RII & $A$ & $B$ & RII & $A$ & $B$ \\
\hline \multicolumn{8}{|c|}{ Process-related factors } \\
\hline $\mathrm{P} 1$ & Changes, modification, and revisions in design/construction changes & 0.841 & 3 & 4 & 0.747 & 1 & 1 \\
\hline P2 & Error in design, drawings, and specifications/error in construction & 0.923 & 1 & 1 & 0.652 & 3 & 5 \\
\hline P3 & Incomplete design, any omission in the design or construction process & 0.894 & 2 & 2 & 0.658 & 2 & 4 \\
\hline P4 & Inadequate procurement methods/poor contract execution & 0.7 & 6 & 15 & 0.552 & 5 & 17 \\
\hline P5 & Improper contractor and subcontractor selection & 0.705 & 5 & 14 & 0.529 & 6 & 20 \\
\hline P6 & Lack of document control & 0.717 & 4 & 12 & 0.582 & 4 & 13 \\
\hline \multicolumn{8}{|c|}{ Human resources-related factors } \\
\hline H1 & Lack of experience and personal expertise in design and construction & 0.77 & 1 & 6 & 0.511 & 6 & 23 \\
\hline $\mathrm{H} 2$ & Inadequate supervision staff & 0.764 & 2 & 7 & 0.517 & 5 & 22 \\
\hline $\mathrm{H} 3$ & Inadequate manpower to complete the task & 0.729 & 4 & 11 & 0.541 & 2 & 19 \\
\hline $\mathrm{H} 4$ & Insufficient skilled level manpower & 0.77 & 1 & 6 & 0.511 & 6 & 23 \\
\hline H5 & Poor knowledge of team member, lack of education and training & 0.741 & 3 & 9 & 0.517 & 5 & 22 \\
\hline H6 & Lack of employee motivation and rewards, carelessness & 0.647 & 6 & 20 & 0.523 & 4 & 21 \\
\hline H7 & Poor workmanship approach and inappropriate personal attitude & 0.711 & 5 & 13 & 0.517 & 5 & 22 \\
\hline $\mathrm{H} 8$ & Absence of job security and other safety rules & 0.482 & 9 & 29 & 0.511 & 6 & 23 \\
\hline H9 & Labor reallocation, alteration, and staff turnover & 0.6 & 7 & 25 & 0.529 & 3 & 20 \\
\hline $\mathrm{H} 10$ & Conflict of interests & 0.505 & 8 & 28 & 0.558 & 1 & 16 \\
\hline \multicolumn{8}{|c|}{ Material and equipment-related factors } \\
\hline M1 & Defective materials, nonadherence to material specifications & 0.735 & 1 & 10 & 0.688 & 1 & 2 \\
\hline M2 & Poor-quality material or substandard products/prefabrication errors & 0.717 & 2 & 12 & 0.670 & 2 & 3 \\
\hline M3 & Replacement or misplacement of material and equipment & 0.623 & 3 & 22 & 0.611 & 3 & 11 \\
\hline M4 & Inefficient equipment use or altered material & 0.611 & 4 & 23 & 0.582 & 4 & 13 \\
\hline M5 & Untimely deliveries of material and equipment & 0.605 & 5 & 24 & 0.558 & 5 & 16 \\
\hline \multicolumn{8}{|c|}{ Technical-related factors } \\
\hline T1 & Ineffective use of quality management practices/deviation due to poor monitoring & 0.752 & 3 & 8 & 0.623 & 3 & 9 \\
\hline $\mathrm{T} 2$ & Poor technology application and lack of information technology use & 0.6 & 6 & 25 & 0.523 & 6 & 21 \\
\hline $\mathrm{T} 3$ & Poor communication system for coordinating between members & 0.688 & 5 & 16 & 0.517 & 7 & 22 \\
\hline $\mathrm{T} 4$ & Inefficient management process, poor site management practice & 0.729 & 4 & 11 & 0.547 & 5 & 18 \\
\hline T5 & Poor project documents, unclear instructions, poor contract documents & 0.817 & 2 & 5 & 0.635 & 2 & 7 \\
\hline T6 & Conflicting and incomplete information & 0.847 & 1 & 3 & 0.670 & 1 & 3 \\
\hline $\mathrm{T} 7$ & Inadequate planning and poor scheduling of workload & 0.752 & 3 & 8 & 0.564 & 4 & 15 \\
\hline \multicolumn{8}{|c|}{ General/external factors } \\
\hline G1 & $\begin{array}{l}\text { Financial issues such as lack of funding, low contract or payment fee, } \\
\text { delay in payment and cost pressure }\end{array}$ & 0.670 & 3 & 18 & 0.576 & 6 & 14 \\
\hline G2 & Lack of client involvement & 0.635 & 5 & 21 & 0.558 & 7 & 16 \\
\hline G3 & Unclear line of authority & 0.594 & 6 & 26 & 0.670 & 1 & 3 \\
\hline G4 & $\begin{array}{l}\text { Time pressure, schedule acceleration to finish the task, insufficient time to } \\
\text { prepare contract documentation }\end{array}$ & 0.752 & 1 & 8 & 0.594 & 5 & 12 \\
\hline G5 & Lack of constructability & 0.752 & 1 & 8 & 0.541 & 8 & 19 \\
\hline G6 & $\begin{array}{l}\text { Damage/defects/deviations in the product due to poor handling and safety } \\
\text { considerations }\end{array}$ & 0.682 & 2 & 17 & 0.594 & 5 & 12 \\
\hline G7 & Governmental regulations/changes and policies & 0.535 & 7 & 27 & 0.641 & 2 & 6 \\
\hline G8 & Environmental conditions, poor site condition & 0.652 & 4 & 19 & 0.629 & 3 & 8 \\
\hline G9 & Unpredictable factors from different sources & 0.652 & 4 & 19 & 0.617 & 4 & 10 \\
\hline
\end{tabular}

Note: $A$ shows ranking of causes under each group and $B$ shows ranking of causes among all groups.

Table 5. Relative importance index of rework group factors

T5:2

$\mathrm{T} 5: 3$

$\mathrm{T} 5: 4$

T5:5

$\mathrm{T} 5: 6$

T5:7

\begin{tabular}{ccccc}
\multicolumn{2}{c}{ Objective 1} & & \multicolumn{2}{c}{ Objective 2 } \\
\cline { 1 - 2 } \cline { 5 - 5 } RII & Rank & & RII & Rank \\
0.797 & 1 & & 0.620 & 2 \\
0.672 & 3 & & 0.524 & 4 \\
0.658 & 4 & & 0.622 & 1 \\
0.741 & 2 & & 0.583 & 3 \\
0.658 & 4 & & 0.620 & 2 \\
\hline
\end{tabular}

are generating contractual claims more than the other groups of factors, followed by technical-related factors and human resources factors. Therefore, these three groups have greater priority for further investigation because they result in higher numbers of claims in projects. In terms of being addressed by contract conditions, the group factors of material and equipment stand higher than the other groups, meaning that the conditions of contract have adequately addressed the causes of rework under this category and more investigation may not be required. The group of human resources-related factors with lower RII has more priority for further investigation because they seemed to be less addressed in the conditions of the contract. Table 4 lists the relative importance index for each of the causes of rework to meet the study's objectives. The result showed that the rework leads to contractual claims under various situations. The causes of rework illustrate the causal relationship between rework and claims. The other side of the result showed that contract conditions do not adequately address the causes of rework, making the assessment of claims even more difficult. When the contract conditions do not provide enough legal evidence for processing claims, they are more likely to lead to conflict and disputes. Based on this result, further investigation on contract conditions is required. 


\begin{tabular}{|c|c|c|c|c|}
\hline \multicolumn{5}{|c|}{ Objective 2} \\
\cline { 2 - 5 }
\end{tabular}

Fig. 3. Matrix of relative importance index of rework causes.

Table 6. Ranking criterion for dividing relative importance index into five levels

T6:1

\begin{tabular}{|c|c|c|c|c|}
\hline \multirow[b]{2}{*}{ Scale } & \multirow{2}{*}{$\begin{array}{l}\text { Level of } \\
\text { importance }\end{array}$} & Objective 1 & Objective 2 & \\
\hline & & Range of RII & Range of RII & Ley \\
\hline $0 \leq$ & Ver & 835 & 0.5 & 1 \\
\hline $20 \%$ & High & 0.83 & 0.559 & 2 \\
\hline $40 \%<x \leq 60 \%$ & Moderate & $0.746-0.658$ & $0.606-0.652$ & 3 \\
\hline $60 \%<x \leq 80 \%$ & Low & $0.657-0.570$ & $0.653-0.700$ & 4 \\
\hline $80 \%<x \leq 100 \%$ & Very low & $0.569-0.482$ & $0.701-0.747$ & 5 \\
\hline
\end{tabular}

A combination of these two importance indexes would facilitate further discussion on the causes of rework in relation to the contractual claims and contract conditions. The listed causes of rework in Table 4 can take two indicators from each objective of the study and make a matrix with two dimensions. Fig. 3 shows the matrix that has been made by RII of the study's objectives. Each objective's RII is divided into five equal parts from top to bottom to show the importance level of causes according to the industry's feedback (Kassem et al. 2020). The level of importance is indicated by very important, important, moderate, less important, much less important. The assessment is based on the matrix scale of the RII value, where the lowest and highest are 0.482 to 0.923 for Objective 1 , and 0.747 to 0.511 for Objective 2 (Husin et al. 2019). The matrix then shows seven different areas that have been colored for identifying the priority of combinations between importance indexes (Luo et al. 2018). Area (VII) that encompasses very high RII in both objectives has the highest priority for further investigation, followed by the areas (VI) and (V). The other areas including (IV), (III), (II), and (I) consist of rework causes that have moderate or lower RII on both sides of the matrix and therefore have less priority for further investigations. A two-dimensional matrix was then used for covering the result and placing each rework cause distributed in the defined zones (Kassem et al. 2019). The result of this combination is presented in Fig. 3.

Table 6 lists the criteria and boundaries for dividing the range of RII in both objectives of the study. Data analysis on Objective 2 showed a range of 0.511 to 0.747 as the relative importance index of each evaluated cause. A higher score shows that respondents are more likely to agree that the condition of the contract adequately addresses the root causes of rework, and a lower score means the causes of rework have not been addressed adequately in the contract conditions. Therefore, the lowest RII in Objective 2 has the highest probability of leading to conflict or dispute because no reference has been placed in the contract conditions. Since the provided list of causes in the survey was not against or aligned with contract parties' interests, it is worth mentioning that the RII result is most likely unbiased; however, the number of participants from the client side was higher than from the contractor side.

\section{Discussion}

\section{Main Source of Claim under Rework Circumstances}

Rework shares a variety of common causes with claims and can be used as a trigger for claim management. Lack of claim management triggers dispute situations that usually lead to a deterioration in the quality of the party's relationship. Contract parties use the identified sources of the claim as evidence for reasoning based on the contract provisions. Nonetheless, identification of the sources of a claim needs to be performed before proposing a solution. Different singular or multiple causes may originate claims and it is critical to understand which combination of causes has made a claim (Jelodar et al. 2016). The relevant importance index of each cause listed under Objective 1 ranks them in terms of their influence in generating contractual claims. Therefore, a higher RII shows more probability of generating a claim from that particular source. The following section first discusses the most influential causes of rework under five categories and then provides a priority list of top causes for future investigations.

Among the six causes under the group of process-related factors, error in design and construction stands as the first rank of causes that highly trigger the generation of claims. Review of the completed design to identify design errors by an expert team has been suggested to be included in standard contract agreements (Mendis et al. 2015). Design error has been also ranked at the top of claim, dispute, and conflict causes in previous studies (Kisi et al. 2020; Saseendran et al. 2020), while Zaneldin (2020) ranked this cause at ninth of 45 reviewed items in the UAE. A large proportion of construction errors are raised due to mistakes in contract documentation (Dosumu 2018) and this cause has been ranked second in the study of dispute causes in Sri Lanka (Illankoon et al. 2019). The RII of the 10 rework causes under the human resources group showed that lack of experienced staff and insufficient skilled level manpower highly generate claims. A study in Egypt also ranked interpersonal skills and construction law experience together in the second level of factors causing construction claims (Mohamed et al. 2014). With a relative importance index of 0.735 , defective materials are ranked as the highest cause compared with the other four causes under the group of material/equipment-related factors. Failure to disclose the used material specification by a contractor was among 13 severe factors influencing construction contract disputes in Nigeria (Aiyewalehinmi and Nkumah 2019).
564

565

566

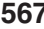


The technical-related factor that comprises seven different causes revealed that conflicting and incomplete information can be the most influential causes in generating a contractual claim. According to Ekhator (2016), a lack of information and conflicting data leads to misunderstanding, and Enshassi et al. (2009) stated that design errors arise from conflicting information; both end with claims. It has also been ascertained that rework is managed well when information is adequate with no conflictions (Oyewobi and Ogunsemi 2010). In the last group of causes, which have been clustered under the name of general/external-related factors, two underlying causes-lack of constructability and time pressures - stand at the top of the list between nine causes. In the list of conflict causes presented by Gajaman et al. (2019), a reluctance to check for constructability is categorized under consultant-related factors. On the other side, time pressure is a common practice for the construction industry; however, it is almost always underestimated by construction practitioners (Palaneeswaran et al. 2007). In the study done in Nigeria (Aiyetan 2013) time pressure ranked sixth under designrelated factors related to the causes of rework. In addition, time pressure is one of the variables of organizational culture that influence rework occurrence (Oyewobi et al. 2016).

\section{Contract Conditions in a Claim Incident from Rework}

The relevant importance index of each cause listed under Objective 2 ranks them in terms of being addressed adequately within NZS 3910 contract conditions. The higher RII of each cause shows more contract conditions coverage that makes for a lower priority for further investigation. Therefore, items with lower relative importance lower rate of RII means that specific rework causes have not been more study to find a solution or provide recommendations for improving relevant clauses of the contract. The initial results of this paper will be used for discussion on the clauses that can be linked to rework. Therefore, the next step of the study provides insight into contract conditions by conducting interviews with legal professionals and construction practitioners to understand how rework can be addressed in the contract to avoid conflicts.

Under the group of process-related factors, changes in design and construction $(\mathrm{RII}=0.747)$ are ranked highest in terms of being addressed in the contract conditions. Change also ranked the highest among all investigated causes. Therefore, it is known as one of the causes that have been covered enough under the examined contract conditions. In the study of claim causes and types in India, eight types of claim were introduced, in which change claim was ranked at the third level after extra work and delay claims (Al-Qershi and Kishore 2017). Change claims also have been identified as the most common type of claim in construction projects (Atanda and Fabi 2015; Hansen 2016; Zaneldin 2020). In contrast, improper contractor and subcontractor selection with an RII of 0.529 ranked as the lowest cause. In other words, the condition of contract has, relatively speaking, addressed this cause less than other causes categorized under this group. Although selection of contractor and subcontractor has been studied adequately under rework circumstances, it seems to have received very limited studies under claim situations. A research study for reducing construction disputes through effective claim management ranked improper contractor selection at eighth among 31 identified factors causing construction claims (Mohamed et al. 2014).

Under human resources-related factors, conflicts of interest with a relative importance index of 0.558 are ranked the highest for referencing in contract conditions. Conflicts of interest as a root cause of rework may not be required to be assessed under claim indexes would have more priority for further investigation. The addressed adequately within the contract conditions, and it requires events because most of the contract conditions cover it in their clauses (Raj et al. 2009). In contrast, lack of experience, insufficient skilled manpower, plus the absence of job security ranked the lowest among all causes, which means that the contract conditions have not covered these root causes of rework adequately compared to the others. Most probably, incorporating these items in the contract provisions is very difficult (Jelodar et al. 2016). Two causesexperienced staff and skilled manpower-are seen in the list of most significant dispute causes in construction projects (Illankoon et al. 2019) but the absence of job security has not been evaluated under claim causes yet. Defective material, one of the main triggers of the claims under the material/equipment group, has been addressed adequately in the contract conditions with the high RII of 0.688. Previous studies also claimed that defective material accounted for $20 \%$ of nonconformance cost of projects (Josephson et al. 2002; Oyewobi and Ogunsemi 2010). Conversely, untimely deliveries of material and equipment with an RII of 0.558 ranked as the lowest; therefore, it has priority for more investigation through the contract conditions. Late supply of material by client makes the contractor eligible for an extension of time claim (El-adaway et al. 2020). Late material delivery is very dependent on the terms and conditions of the contract when categorized under a construction change order (Hansen et al. 2020).

Under the technical-related factor group of causes, the highest and lowest identified causes are conflicting and incomplete information and poor communication system for coordinating between members with RIIs of 0.670 and 0.517 , in which the lowest one needs more investigation within the contract conditions. Poor information generates project uncertainties (Eze et al. 2018a) and uncertainty has been identified as the third most common causes of claim (Jelodar et al. 2016). Previous studies also stressed that poor communication among project parties may lead to claims and conflict (Mahamid 2016a). Poor communication has also been identified as a critical item in rework occurrences by a number of studies (Eze et al. 2018a; Ye et al. 2015). The cause with RII of 0.670, namely, the unclear line of authority, is ranked as the first item, and lack of constructability with the relevant importance index of 0.541 is ranked as the last cause under the group of general/external causes that has more priority for exploring the contract conditions. The line of authority generally lies with the role of the engineer in most standard forms of contract worldwide in which clauses of the contract clearly make reference to them (El-adaway et al. 2016). Lack of constructability was not listed under causes of claim in the study done by Zaneldin (2020) but implementing constructability during various stages of a project is one of the author's suggested solutions for preventing claims.

The priority list of rework causes for further investigation as the main contribution of this paper is presented in Table 7. This list narrows down only to the causes that need to be focused on for the next research steps through interviews. The priority list was extracted based on the importance areas of the matrix and clustered causes with the same level of importance in three clusters.

\section{Conclusion}

This paper aims to provide basic information for further studying the relationship between rework and claims by investigating rework causes in construction contracts. Various practical works and theories were employed to reduce or manage claims through the years, but a general agreement has yet to be reached on the relationship between the causes of rework and contractual claims. The paper explores whether the general conditions of contract address the identified causes of rework from the literature or not. A foundation for 
Table 7. Priority list of rework causes for further investigation in the general conditions of the contract NZS3910

T7:2

\begin{tabular}{|c|c|c|c|}
\hline Priority & Root causes of rework & Code & Group factor \\
\hline \multicolumn{4}{|c|}{ (1) Cluster of causes in "VII area of Fig. 3" } \\
\hline 1 & Lack of experience and personal expertise in design and construction & H1 & Human resources \\
\hline 1 & Inadequate supervision staff & $\mathrm{H} 2$ & Human resources \\
\hline 1 & Insufficient skilled level manpower & $\mathrm{H} 4$ & Human resources \\
\hline 1 & Lack of constructability & G5 & General/external \\
\hline \multicolumn{4}{|c|}{ (2) Cluster of causes "VI area of Fig. 3" } \\
\hline 2 & Error in design, drawings and specifications/error in construction & $\mathrm{P} 2$ & Process \\
\hline 2 & Inadequate procurement methods/poor contract execution & $\mathrm{P} 4$ & Process \\
\hline 2 & Improper contractor and subcontractor selection & P5 & Process \\
\hline 2 & Inadequate manpower to complete the task & H3 & Human resources \\
\hline 2 & Poor knowledge of team member, lack of education and training & H5 & Human resources \\
\hline 2 & Poor workmanship approach and inappropriate personal attitude & $\mathrm{H} 7$ & Human resources \\
\hline 2 & Poor communication system for coordinating between members & $\mathrm{T} 3$ & Technical \\
\hline 2 & Inefficient management process, poor site management practice & $\mathrm{T} 4$ & Technical \\
\hline 2 & Inadequate planning and poor scheduling of workload & $\mathrm{T} 7$ & Technical \\
\hline 2 & Time pressure, schedule acceleration to finish the task, insufficient time to prepare contract documer & G4 & General/external \\
\hline \multicolumn{4}{|c|}{ (3) Cluster of causes in "V area of Fig. 3" } \\
\hline 3 & Incomplete design, any omission in the design or construction process & $\mathrm{P} 3$ & Process \\
\hline 3 & Lack of document control & P6 & Process \\
\hline 3 & Lack of employee motivation and rewards, Carelessness & H6 & Human resources \\
\hline 3 & Labor reallocation, alteration and staff turnover & H9 & Human resources \\
\hline 3 & Untimely deliveries of material and equipment & M5 & Material/equipment \\
\hline 3 & Ineffective use of quality management practices/deviation due to poor monitoring & $\mathrm{T} 1$ & Technical \\
\hline 3 & Poor technology application and lack of information technology use & $\mathrm{T} 2$ & Technical \\
\hline 3 & Poor project documents, unclear instructions, poor contract documents & T5 & Technical \\
\hline 3 & Conflicting and incomplete information & T6 & Technical \\
\hline 3 & Financial issues such as lack of funding, low contract or payment fee, delay in payment and cost pressure & G1 & General/external \\
\hline 3 & Lack of client involvement & G2 & General/external \\
\hline 3 & Damage/defects/Deviations in the product due to poor handling and safety considerations & G6 & General/external \\
\hline
\end{tabular}

this study was established by conducting a comprehensive literature review to identify the causes of rework in the first instance. Over the past 30 years, considerable literature has been directed to research rework issues in construction projects. Adequate sample cases using various strategies have been reported for reducing or preventing the impacts of rework globally. Content analysis of the papers revealed that a large proportion of rework studies have focused on rework root causes, explaining that a great effort has been made to understand the nature of rework. The comprehensive literature review identified 37 root causes of rework, classified into five distinct groups for further investigation. Based on the classified causes of rework, a survey questionnaire was designed and distributed to the industry to examine the relationship between identified rework causes and contractual claims, and to explore the adequacy of the general conditions of contract in addressing rework. The identification of rework causes that affect contractual claims can assist in

The ultimate goal of the survey was to find the most important causes of rework that have not been addressed in the contract conditions. For this purpose, after collecting an adequate number of responses on the survey, the initial analysis using the method of RII was performed to prioritize the most significant causes of rework. The performed analysis ranked rework causes in terms of not being addressed by the contract conditions of the most commonly used standard form in New Zealand, NZS 3910. This initial result showed that the general conditions of NZS 3910 do not address the causes of rework adequately. As such, this exploratory study needs more empirical investigations with construction professionals to improve contract conditions. Further investigation into the clauses of the contract could be developed on the basis of feedback from the industry for addressing rework in contract conditions. A developed framework could enable contractual parties to manage their reducing construction disputes. aspects during the handling of claims as a result of rework. Thus, the concluded result from the initial analysis of this paper will be used for the interview questions to find the solutions for improving contract conditions during rework circumstances.

The result of this paper is limited to the contract conditions contained in NZS 3910 and cannot be extended to other standard forms of contract. Also, the study may be limited by the higher number of responses from the client side compared to the contractor side. This tives. Future investigations could ensure a balanced proportion of study participants, if indeed this had any effect on study findings. Finally, the small sample size in the current study confines the generalization of the findings, but the study's contribution provided evidence that some causes of rework can quickly trigger the occurrence of a claim. Therefore, empirical testing with a larger sample accompanied with validation interviews could address these limitations.

\section{Data Availability Statement}

All data, models, and code generated or used during the study appear in the published article.

\section{References}

\section{Works Cited}

Abdul-Malak, M.-A. U., A. H. Srour, and F. S. Demachkieh. 2020. "Decision-making governance platforms for the progression of construction claims and disputes." J. Leg. Aff. Dispute Resolut. Eng. may have the effect of skewing the results toward client perspec- 
Constr. 12 (3): 04520025. https://doi.org/10.1061/(ASCE)LA.1943 -4170.0000412 .

Ahmed, S. A., and B. H. Naik. 2016. "Rework management in construction projects and comparison with time and cost." Int. J. Innovative Res. Sci. Eng. Technol. 5 (10): 17973-17980. https://doi.org/10.15680/IJIRSET .2016 .0510102 .

Aiyetan, A. O. 2013. "Causes of rework on building construction projects in Nigeria." Interim Interdiscip. J. 12 (3): 1-15.

Aiyetan, O. A., and D. Das. 2015. "Using system dynamics modelling principles to resolve problems of rework in construction projects in Nigeria." J. Constr. Project Manage. Innovation 5 (2): 1266-1295. https://doi.org /10.36615/jcpmi.v5i2.91.

Aiyewalehinmi, E. O., and L. Nkumah. 2019. "Evaluation of construction contract dispute between the clients and contractor in Nigeria: Ondo state as a case study." Eur. J. Eng. Technol. 7 (3): 40-55.

Ajayi, O., and O. Oyeyipo. 2015. "Effect of rework on project performance in building project in Nigeria." Int. J. Eng. Res. Technol. 4 (2): 294-300.

Ajayi, O. M. 2017. "Occurrence of rework on components of building project in Lagos state, Nigeria." Int. J. Sustainable Constr. Eng. Technol. 8 (1): 84-93.

Alaghbari, W., A. A. Al-Sakkaf, and B. Sultan. 2018. "Factors affecting construction labour productivity in Yemen." Int. J. Constr. Manage. 19 (1): 79-91. https://doi.org/10.1080/15623599.2017.1382091.

Al-Janabi, A. M., M. S. Abdel-Monem, and K. M. El-Dash. 2020. "Factors causing rework and their impact on projects performance in Egypt." J. Civ. Eng. Manage. 26 (7): 666-689. https://doi.org/10.3846/jcem .2020 .12916 .

Al-Qershi, M. T., and R. Kishore. 2017. "Claim causes and types in Indian construction industry-Contractor's perspective." Am. J. Civ. Eng. Archit. 5 (5): 196-203.

Anjum, S., and F. Azam. 2019. "Time and cost impacts of rework in building construction projects." J. Innovative Dev. Pharm. Tech. Sci. 2 (4): 74-84.

Atanda, A. O., and J. K. Fabi. 2015. "Assessment of claims management on building projects in Nigeria." In Proc., 5th National Conf. of the School of Environmental Studies, Federal Polytechnic, Ilaro, 1-12. Ilaro, Nigeria: Federal Polytechnic, Ilaro.

Banwo, O., K. Parker, and A. Sagoo. 2015. "Principles of contract claims management-A review of the Nigerian construction industry." In Proc., Int. Conf. on Industrial Engineering and Operations Management, Dubai, (UAE). New York: IEEE. https://doi.org/10.1109/IEOM.2015 7093726 .

Besaiso, H., P. Fenn, M. Emsley, and D. Wright. 2018. "A comparison of the suitability of FIDIC and NEC conditions of contract in Palestine." Eng. Constr. Archit. Manage. 25 (2): 241-256. https://doi.org/10.1108 /ECAM-10-2016-0235.

Choi, S. H., and Y. S. Kim. 2016. "Priority analysis of dispute factors in overseas construction based on FIDIC contract conditions." KSCE J. Civ. Eng. 20 (6): 2124-2133. https://doi.org/10.1007/s12205-015 $-0174-x$.

Dosumu, O. S. 2018. "Perceived effects of prevalent errors in contract documents on construction projects." Constr. Econ. Build. 18 (1): 1-26. https://doi.org/10.5130/AJCEB.v18i1.5663.

Ekhator, O. J. 2016. "Investigating causes of disputes in building construction projects in Nigeria.” Int. J. Sci. Environ. Technol. 5 (5): 3516-3527.

El-adaway, I. H., I. S. Abotaleb, M. S. Eid, S. May, L. Netherton, and J. Vest. 2018. "Contract administration guidelines for public infrastructure projects in the United States and Saudi Arabia: Comparative analysis approach.” J. Constr. Eng. Manage. 144 (6): 04018031. https://doi .org/10.1061/(ASCE)CO.1943-7862.0001472.

El-adaway, I. H., S. Fawzy, T. Allard, and A. Runnels. 2016. "Change order provisions under national and international standard forms of contract." J. Leg. Aff. Dispute Resolut. Eng. Constr. 8 (3): 03716001. https://doi .org/10.1061/(ASCE)LA.1943-4170.0000187.

El-adaway, I. H., R. A. Vance, and I. S. Abotaleb. 2020. "Understanding extension of time under different standard design-build forms of contract." J. Leg. Aff. Dispute Resolut. Eng. Constr. 12 (1): 04519031. https://doi.org/10.1061/(ASCE)LA.1943-4170.0000331.
Enshassi, A., R. M. Choudhry, and S. El-Ghandour. 2009. "Contractor's perception towards causes of claim in construction projects." Int. J. Constr. Manage. 9 (1): 79-92. https://doi.org/10.1080/15623599.2009 .10773123 .

Enshassi, A., M. Sundermeier, and M. Abo Zeiter. 2017. "Factors contributing to rework and their impact on construction projects performance." Int. J. Sustainable Constr. Eng. Technol. 8 (1): 12-33.

Eze, E. C., and J. E. Idiake. 2018. "Impact of rework on building project and organisation performance: A view of construction professionals in Nigeria." Int. J. Sustainable Constr. Eng. Technol. 9 (1): 29-44.

Eze, E. C., J. E. Idiake, and B. O. Ganiyu. 2018a. "Analysis of rework risk triggers in the Nigerian construction industry." Organ. Technol. Manage. Constr. 10 (1): 1778-1793. https://doi.org/10.2478/otmcj-2018-0008.

Eze, E. C., J. E. Idiake, and B. O. Ganiyu. 2018b. "Rework risks triggers in the Nigerian construction industry a view of built environment professionals." Independent J. Manage. Prod. 9 (2): 448-472. https:// doi.org/10.14807/ijmp.v9i2.729.

Forcada, N., G. Rusinol, M. Macarulla, and P. E. D. Love. 2014. "Rework in highway projects." J. Civ. Eng. Manage. 20 (4): 445-465. https://doi .org/10.3846/13923730.2014.893917.

Gajaman, K., V. Disaratna, P. Ganeshu, and F. S. Nazeer. 2019. "Conflict avoidance in construction stage through proper practice in pre-contract stage." In Proc., Int. Conf. on Industrial Engineering and Operations Management, 2624-2635. Southfield, MI: IEOM Society International.

Gamil, Y., and I. A. Rahman. 2020. "Assessment of critical factors contributing to construction failure in Yemen." Int. J. Constr. Manage. 20 (5): 429-436. https://doi.org/10.1080/15623599.2018.1484866.

Gunduz, M., and H. A. Elsherbeny. 2020. "Operational framework for managing construction-contract administration practitioners' perspective through modified Delphi method." J. Constr. Eng. Manage. 146 (3): 04019110. https://doi.org/10.1061/(ASCE)CO.1943-7862.0001768.

Hansen, S. 2016. "Investigation of types and causes of construction claims in Indonesia." In Prosiding Seminar Nasional Aplikasi Teknologi Prasarana Wilayah IX (ATPW). Jawa Timur, Indonesia: Sepuluh Nopember Institute of Technology.

Hansen, S., S. F. Rostiyanti, and A. Rif'at. 2020. "Causes, effects, and mitigations framework of contract change orders: Lessons learned from GBK aquatic stadium project." J. Leg. Aff. Dispute Resolut. Eng. Constr. 12 (1): 05019008. https://doi.org/10.1061/(ASCE)LA.1943-4170.0000341.

Husin, S., M. R. Abdullah, and M. Afifuddin. 2019. "Assessment of external risk factors on construction project schedule using risk importance index (RII).” Pertanika J. Sci. Technol. 27 (4): 2031-2047.

Hwang, B. G., M. Shan, and E. K. Tan. 2016. "Investigating reworks in green building construction projects magnitude influential factors, and solutions." Int. J. Environ. Res. 10 (4): 499-510.

Hwang, B. G., and S. Yang. 2014. "Rework and schedule performance; A profile of incidence, impact, causes and solutions." Eng. Constr. Archit. Manage. 21 (2): 190-205. https://doi.org/10.1108/ECAM-10-2012 -0101 .

Hwang, B. G., X. Zhao, and K. J. Goh. 2014. "Investigating the clientrelated rework in building projects: The case of Singapore." Int. J. Project Manage. 32 (4): 698-708. https://doi.org/10.1016/j.ijproman 2013.08.009.

Hwang, B.-G., X. Zhao, and K. W. Yang. 2019. "Effect of BIM on rework in construction projects in Singapore: Status quo, magnitude, impact, and strategies." J. Constr. Eng. Manage. 145 (2): 04018125. https://doi .org/10.1061/(ASCE)CO.1943-7862.0001600.

Illankoon, I. M. C. S., V. W. Y. Tam, K. N. Le, and K. A. T. O. Ranadewa. 2019. "Causes of disputes, factors affecting dispute resolution and effective alternative dispute resolution for Sri Lankan construction industry." Int. J. Constr. Manage. https://doi.org/10.1080/15623599.2019 .1616415 .

Jelodar, M. B., T. W. Yiu, and S. Wilkinson. 2016. "Dispute manifestation and relationship quality in practice." J. Leg. Aff. Dispute Resolut. Eng. Constr. 8 (1): C4515003. https://doi.org/10.1061/(ASCE)LA.1943-4170 .0000171 .

Josephson, P.-E., B. Larsson, and H. Li. 2002. "Illustrative benchmarking rework and rework costs in Swedish construction industry." J. Manage. Eng. 18 (2): 76-83. https://doi.org/10.1061/(ASCE)0742-597X(2002) 18:2(76). 
Kassem, M. A., M. A. Khoiry, and H. Hamzah. 2019. "Using probability impact matrix (PIM) in analyzing risk factors affecting the success of oil and gas construction projects in Yemen." Int. J. Energy Sect. Manage. 14 (3): 527-546. https://doi.org/10.1108/IJESM-03-2019-0011.

Kassem, M. A., M. A. Khoiry, and H. Hamzah. 2020. "Using relative importance index method for developing risk map in oil and gas construction projects." Jurnal Kejuruteraan 32 (3): 441-453.

Kim, Y. J., and M. J. Skibniewski. 2020. "Cash and claim: Data-based inverse relationships between liquidity and claims in the construction industry." J. Leg. Aff. Dispute Resolut. Eng. Constr. 12 (3): 04520021. https://doi.org/10.1061/(ASCE)LA.1943-4170.0000402.

Kisi, K. P., N. Lee, R. Kayastha, and J. Kovel. 2020. "Alternative dispute resolution practices in international road construction contracts." J. Leg. Aff. Dispute Resolut. Eng. Constr. 12 (2): 04520001. https://doi.org/10 .1061/(ASCE)LA.1943-4170.0000373.

Lee, Z. P., A. R. Rahimi, and S. I. Doh. 2020. "Critical success factors for implementing design-build: Analysing Malaysian public projects." J. Eng. Des. Technol. https://doi.org/10.1108/JEDT-08-2020-0321.

Lessing, B., D. Thurnell, and S. Durdyev. 2017. "Main factors causing delays in large construction projects: Evidence from New Zealand." J. Manage. Econ. Ind. Organ. 1 (2): 63-82. https://doi.org/10.31039 /jomeino.2017.1.2.5.

Liu, Q., G. Ye, Y. Feng, C. Wang, and Y. Peng. 2020. "Case based insights into rework costs of residential building projects in China." Int. J. Constr. Manage. 20 (4): 347-355. https://doi.org/10.1080/15623599 .2018.1484856.

Love, P. E. D., and J. Curtin. 2020. "Creating a mindfulness to learn from errors enablers of rework containment and reduction in construction." Dev. Built Environ. 1.

Love, P. E. D., D. J. Edwards, and J. Smith. 2006. "Contract documentation and the incidence of rework in projects." Archit. Eng. Des. Manage. 1 (4): 247-259. https://doi.org/10.1080/17452007.2005.9684596.

Love, P. E. D., D. J. Edwards, J. Smith, and D. H. T. Walker. 2009. "Divergence or congruence? A path model of rework for building and civil engineering projects." J. Perform. Constr. Facil. 23 (6): 480-488. https://doi.org/10.1061/(ASCE)CF.1943-5509.0000054.

Love, P. E. D., D. J. Edwards, H. Watson, and P. Davis. 2010. "Rework in civil infrastructure projects: Determination of cost predictors." J. Constr. Eng. Manage. 136 (3): 275-282. https://doi.org/10.1061/(ASCE)CO .1943-7862.0000136.

Love, P. E. D., and J. Smith. 2003. "Benchmarking, benchaction, and benchlearning: Rework mitigation in projects." J. Manage. Eng. 19 (4): 147-159. https://doi.org/10.1061/(ASCE)0742-597X(2003)19: 4(147).

Luo, T., C. Wu, and L. Duan. 2018. "Fishbone diagram and risk matrix analysis method and its application in safety assessment of natural gas spherical tank." J. Cleaner Prod. 174 (Feb): 296-304. https://doi.org/10 .1016/j.jclepro.2017.10.334.

Mahamid, I. 2016a. "Analysis of rework in residential building projects in Palestine." Jordan J. Civ. Eng. 10 (2): 197-208. https://doi.org/10 .14525/JJCE.10.1.3536.

Mahamid, I. 2016b. "Effect of change orders on rework in highway projects in Palestine." J. Financ. Manage. Property Constr. 22 (1): 62-76. https://doi.org/10.1108/JFMPC-03-2016-0015.

Mahamid, I. 2020. "Impact of rework on material waste in building construction projects." Int. J. Constr. Manage. 1-8. https://doi.org/10.1080 /15623599.2020.1728607.

Mendis, D., K. N. Hewage, and J. Wrzesniewski. 2013. "Reduction of construction wastes by improving construction contract management: A multinational evaluation.” Waste Manage. Res. 31 (10): 1062-1069. https://doi.org/10.1177/0734242X13495724.

Mendis, D., K. N. Hewage, and J. Wrzesniewski. 2015. "Contractual obligations analysis for construction waste management in Canada." J. Civ. Eng. Manage. 21 (7): 866-880. https://doi.org/10.3846/13923730 .2014 .893907 .

Miri, M., and M. Khaksefidi. 2015. "Cost management in construction projects rework and its effects." Mediterr. J. Social Sci. 6 (6): 209-215.
Mohamed, H. H., A. H. Ibrahim, and A. A. Soliman. 2014. "Reducing construction disputes through effective claims management." Am. J. Civ. Eng. Archit. 2 (6): 186-196. https://doi.org/10.12691/ajcea-2-6-2.

Moza, A., and V. K. Paul. 2018. "Analysis of claims in public works construction contracts in India." J. Constr. Dev. Countries 23 (2): 7-26. https://doi.org/10.21315/jedc2018.23.2.2.

Ndwandwa, S., E. K. Simpeh, and J. J. Smallwood. 2017. "Factors influencing the occurrence of rework in construction." In Proc., Int. Research Conf. 2017, Sharping Tomorrow's-Built Environment, 757-770. Ottawa: International Council for research and innovation in Building and Construction.

Oyewobi, L. O., O. A. Falemu, and O. T. Ibironke. 2016. "The impact of rework and organisational culture on project delivery." J. Eng. Des. Technol. 14 (2): 214-237. https://doi.org/10.1108/JEDT-05-2013 -0038 .

Oyewobi, L. O., and D. R. Ogunsemi. 2010. "Factors influencing rework occurrence in construction: A study of selected building projects in Nigeria." J. Build. Perform. 1 (1): 1-20.

Palaneeswaran, E. 2006. "Reducing rework to enhance project performance levels." In Proc., One-Day Seminar on Recent Developments in Project Management, 1-10. Hong Kong: Univ. of Hong Kong.

Palaneeswaran, E., M. M. Kumaraswamy, S. T. Ng, and P. E. D. Love. 2006. "Neural network modelling for rework related cost overrun and contractual claims in construction projects." In Proc., Int. Conf. on Computing and Decision Making in Civil and Building Engineering, 1393-1402. Sao Paulo: International Conference on Computing in Civil and Building Engineering.

Palaneeswaran, E., P. E. D. Love, and M. M. Kumaraswamy. 2008. "Mapping rework causes and effects using artificial neural networks." Build. Res. Inf. 36 (5): 450-465. https://doi.org/10.1080/09613210802128269.

Palaneeswaran, E., P. E. D. Love, M. M. Kumaraswamy, and T. S. T. Ng. 2014. "Causal ascription of rework in building and civil engineering projects: A multivariate exploration." Eng. Constr. Archit. Manage. 21 (1): 111-126. https://doi.org/10.1108/ECAM-04-2010-0029.

Palaneeswaran, E., M. Ramanathan, and T. Chi-ming. 2007. "Rework in projects: Learning from errors." Surv. Built Environ. 18 (2): 47-58.

Palaneeswarane, E., M. M. Kumaraswamy, S. T. Ng, and P. E. D. Love. 2005. "A framework for monitoring rework in building projects." In Proc., Tall Buildings, from Engineering to Sustainability, Edition: 2005, Part 13, 710-715. Pokfulam, Hong Kong: HKU Research Services.

Raj, S., J. B. Hillig, and W. Hughes. 2009. "Responsiveness to change by standard-form contract drafters in the construction industry: A case study of the FIDIC White Book." Int. J. Law Built Environ. 1 (3): 205-220. https://doi.org/10.1108/17561450911001261.

Robinson, F. A., M. Dissanayake, and O. Campero. 2004. "Developing a standard methodology for measuring and classifying construction field rework." Can. J. Civ. Eng. 31 (6): 1077-1089. https://doi.org/10.1139 /104-068.

Safapour, E., and S. Kermanshachi, and P. Taneja. 2019. "Investigation and analysis of the rework leading indicators in construction projects stateof-the-art review." In Proc., 7th CSCE Int. Construction Specialty Conf. (ICSC), 1-10. Laval, Canada: Croître avec les jeunes.

Salihu, C., and S. A. Babarinde. 2020. "Strategies for reduction of designrelated rework in the Nigerian construction industry." PM World $J$ 9 (2): 1-11.

Saseendran, A., B. F. Bigelow, Z. K. Rybkowski, and D. E. Jourdan. 2020. "Disputes in construction: Evaluation of contractual effects of ConsensusDOCS." J. Leg. Aff. Dispute Resolut. Eng. Constr. 12 (2): 04520008. https://doi.org/10.1061/(ASCE)LA.1943-4170.0000377.

Shah, K. K., R. A. Shah, and N. D. Sharma. 2016. "Development of field rework index to minimize the impact of rework for effective construction work." Int. J. Sci. Dev. Res. 1 (5): 370-375.

Standard New Zealand. 2013. Conditions of contract for building and civil engineering construction published. NZS 3910-2013. : Wellington, New Zealand.

Trach, R., K. Pawluk, and M. Lendo-Siwicka. 2019. "Causes of rework in construction projects in Ukraine." Archiv. Civ. Eng. 65 (3): 61-74. https://doi.org/10.2478/ace-2019-0034.
1016 
Wang, C., J. B. H. Yap, L. C. Wood, and H. Abdul-Rahman. 2019. "Knowledge modelling for contract disputes and change control." Prod. Plann. Control 30 (8): 650-664. https://doi.org/10.1080/09537287.2019 .1572247.

Wilson, J. U., and I. A. Odesola. 2017. "Design-related causes of rework and the performance of oil and gas projects in Nigeria." Int. J. Sustainable Constr. Eng. Technol. 8 (1): 60-76.

Yap, J. B. H., P. L. Low, and C. Wang. 2017. "Rework in Malaysian building construction impacts causes and potential solutions." J. Eng. Des. Technol. 15 (5): 591-618. https://doi.org/10.1108/JEDT-01-2017 -0002 .
Ye, G., Z. Jin, B. Xia, and M. Skitmore. 2015. "Analyzing causes for reworks in construction projects in China." J. Manage. Eng. 31 (6): 04014097. https://doi.org/10.1061/(ASCE)ME.1943-5479.0000347.

Zaneldin, E. K. 2020. "Investigating the types, causes and severity of claims in construction projects in the UAE." Int. J. Constr. Manage. 20 (5): 385-401. https://doi.org/10.1080/15623599.2018 .1484863 .

Zhang, D., C. T. Haas, P. M. Goodrum, C. H. Caldas, and R. Granger. 2012. "Construction small-projects rework reduction for capital facilities." J. Constr. Eng. Manage. 138 (12): 1377-1385. https://doi.org/10.1061 /(ASCE)CO.1943-7862.0000552.
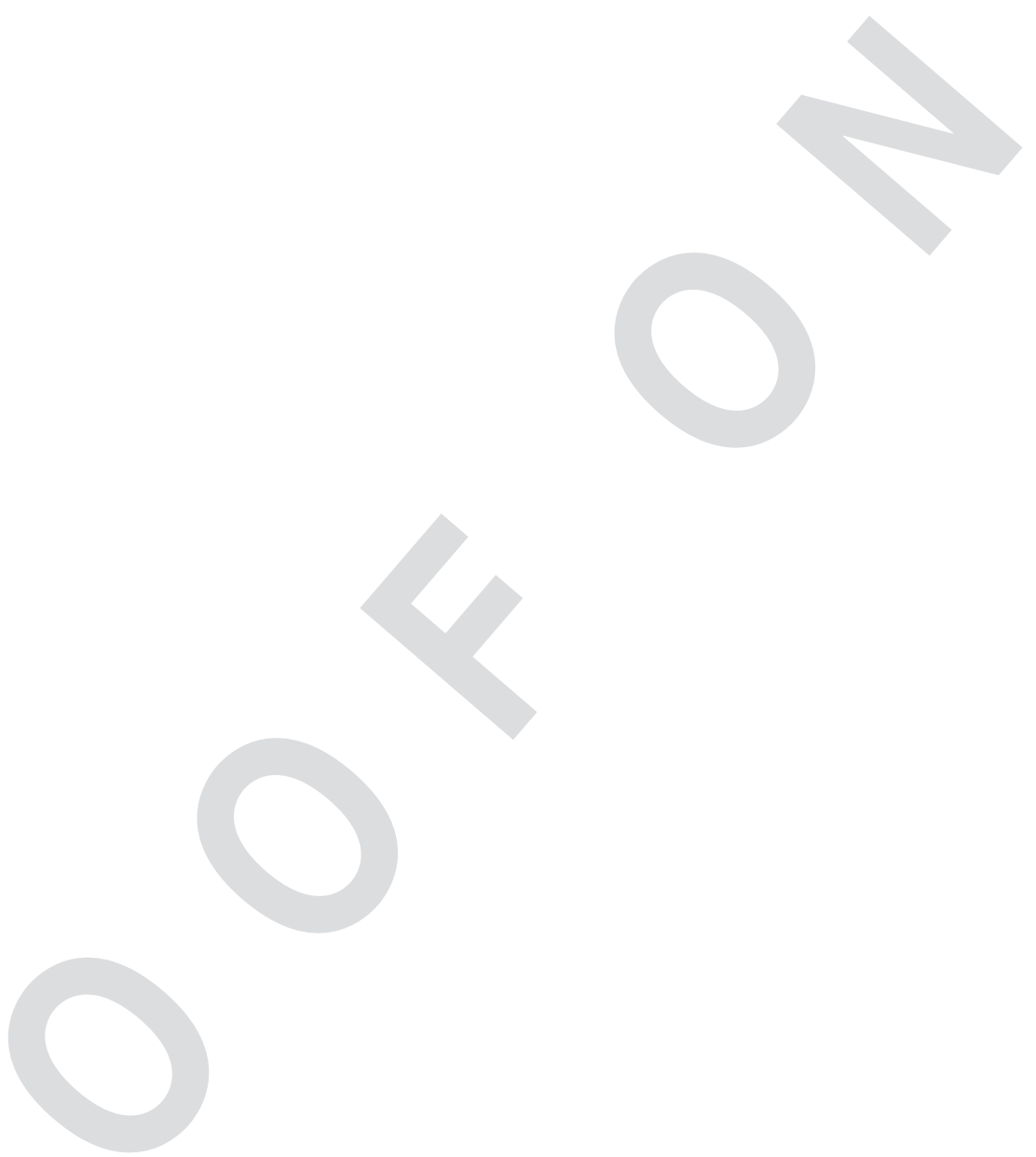



\title{
Investigating the relationship between
} reworks and contractual claims: The salience of contract conditions

\author{
Asadi, R \\ 2022-02-01 \\ http:/hdl.handle.net/10179/16869 \\ 22/04/2023 - Downloaded from MASSEY RESEARCH ONLINE
}

